\title{
IAMJ
}

INTERNATIONAL AYURVEDIC MEDICAL JOURNAL

\section{ART OF COOKING W.S.R CHILD NUTRITION - A PROSPECTIVE STUDY}

\section{$\underline{\text { Manjula }}$}

Assistant Professor in the DEPT of Ayurveda Samhita And Siddhanta, N. K. Jabshetty Ayurveda Medical College, Bidar, Karnataka, India

Corresponding Author: manjulahaiyalkar06@gmail.com

https://doi.org/10.46607/iamj3309042021

(Published Online: April 2021)

Open Access

(C) International Ayurvedic Medical Journal, India 2021

Article Received: 09/04/2021 - Peer Reviewed: 13/04/2021 - Accepted for Publication: 14/04/2021

\section{Check for updates}

\section{ABSTRACT}

Ayurveda, the age-old science of longevity has its own unique approach with childhood nutritional disorders. Ahara is one among three pillars of Ayurveda ${ }^{1}$. Many common health problems can be prevented through healthy diet. When one consumes the Ahara i.e. food in proper quantity and quality and also with The Ishta Gandha, Ishta Varna, Ishta Rasa it leads to improvement or maintenance of the Bala, Varna, ojus ${ }^{2}$. So, Ahara plays a very important role in child nutrition to improve the immunity of the child and to maintain the healthy status of child. As mother plays a very important role in preparing the food, it is in the hand of the mother, how she cooks the food by using the innovative ideas to fill the stomach of the child with the nutritious food ingredients with the attractive colour, shapes and taste. So, here an effort is made to prepare some of the food articles which looks like junky, but they are the healthy and nutritious food to provide the required nutrition to the child in the form of different forms of cooking, which helps the mother to cook the food with the innovative ideas.

Keywords: Ahara, Ayurveda Cooking, Junk food.

\section{INTRODUCTION}

Ayurveda has given prime significance for nutrition and dietary practices and Ahara is considered as one among the three pillars supporting life (Traya Upasthambha). Excellence of ingested food is an important factor which is responsible for proper growth and development. Dietary requirement of an individual varies with age, sex and physical activities so that it provides sufficient energy for all life processes, growth, 
repair and maintenance. So, selection of proper diet is considered as the corner stone of health, especially in the case of young children whose growth and development occurs at a rapid pace. As per Acharya Kashyapa place, time and digestive capacity should not be transgressed while selecting diet for children ${ }^{3}$. Ayurveda considers diet as the greatest medicament and if nourishment is proper it imparts satisfaction, nutrition, patience, intellect, enthusiasm, virility, strength, good voice, ojas, glow, longevity, radiance etc ${ }^{4}$. Optimal feeding of child with adequate nutrients is regarded as the most effective method to attain proper growth and development which occurs at a rapid pace during the first few years of life. Failure of this can cause adverse effects on health of the child. The National Family Health Survey (NFHS)-4 (2015-16) indicates that $35.7 \%$ children below five years are underweight, $38.4 \%$ are stunted and $21 \%$ are wasted in the country. Child undernutrition is an underlying cause in an estimated $35 \%$ of all deaths among children under five years and $21 \%$ of total global disability adjusted life years lost among under 5 age group of children. Undernutrition is strongly associated with shorter adult height, less schooling, reduced economic productivity and for women, lower offspring birthweight, for a mother it is a very difficult task to cook the food with innovative approach.

Materials- Ayurveda Samhitas, articles, net sources

Method-Conceptual, prospective study

\section{Review of Literature}

Malnutrition in Ayurveda is called as Karshya. The signs and symptoms of Karshya mentioned in Ayurveda (wasted muscles over buttocks, abdomen and neck, prominent veins etc) has close proximity with the signs and symptoms of undernourished children. The cause of Karshya is explained as the excess intake of dry food items (biscuits, rusks, namkeen, bread etc.), excessive intake of Katu, Kashaya Rasa, junk foods like pizza, burger, noodles, maggi etc \& less intake of nutritional food. Art of cooking plays a very important role to overcome this type of food habits, how to substitute the maggi with healthy maggi, junk pizza with healthy pizza junky food habits to healthy nutritious food habits is dependent on mother.

\section{DISCUSSION}

1. FFC - Fresh fruit cut lollipop -Any fresh fruit to be cut in different shapes and dipped in the chocolate sauce -

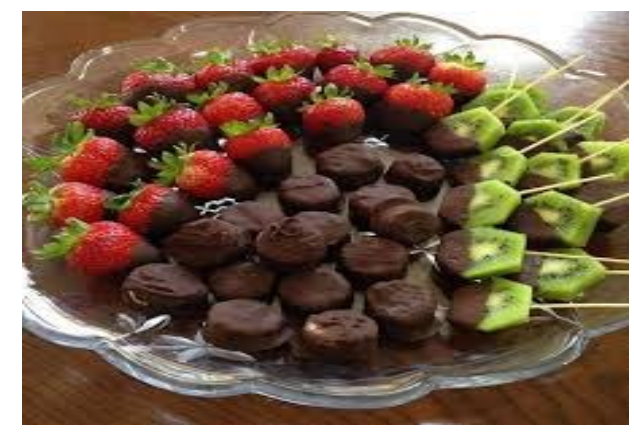

2.Healthy pizza- Pizza dough to be prepared with the Palak puree, beetroot puree, Methi leaves, carrot juice.

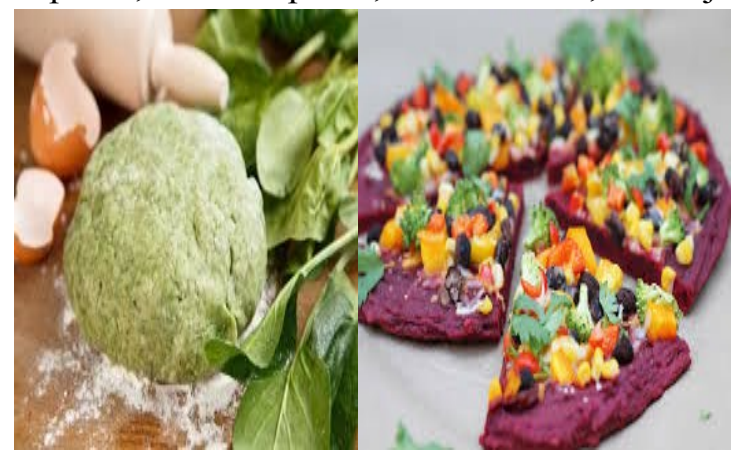

3.Hara bara noodles/maggi- Noodles dough is to be prepared with the Palak puree, carrot juice, beetroot juice.

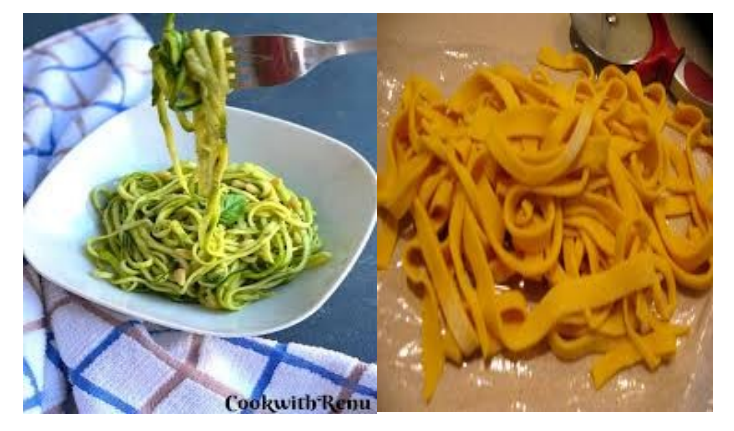

4.Colourful magical dosas-dosa batter mixed with the puree of the carrot, beetroot, cucumber etc and naming them as pink dosa, green dosa etc. 


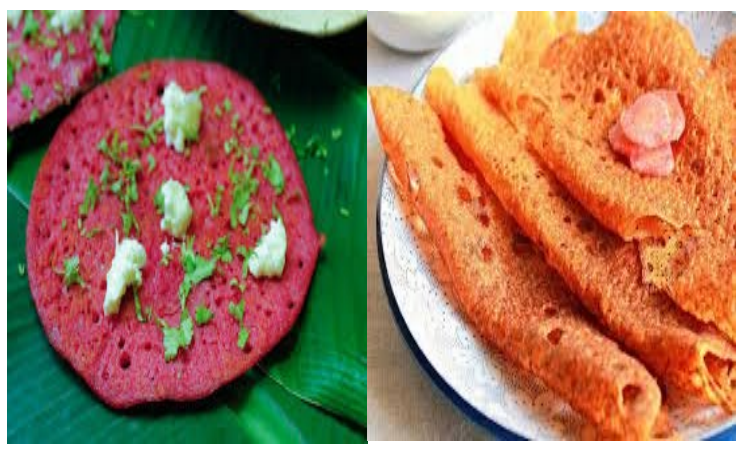

5.Digestive ice creams-with the puree of the pudina, honey, pinch of ginger, Jeeraka and any fresh fruit chunks with fresh fruit candies.

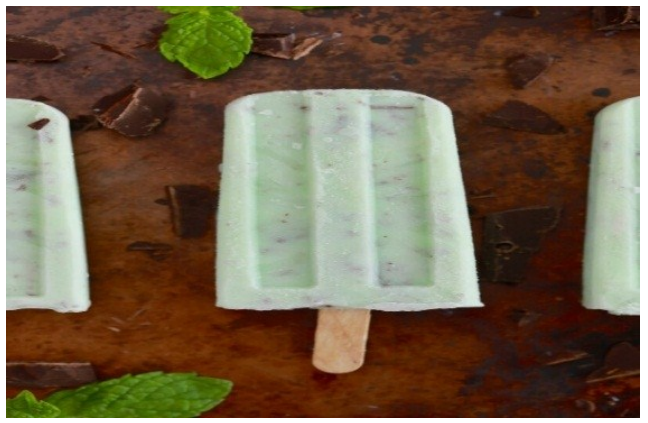

6.Dry fruit Chikki- mixture of dry fruits added to the Chikki base.

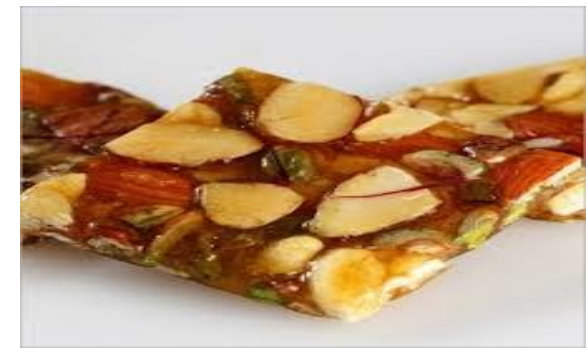

7.Homemade chips to be filled in empty Kurkure packets to attract the children- multigrain flour to be used adding the spices and smashed potatos and given the shapes of Kurkure fried in ghee.

Nowadays children are more attracted towards junk foods, by its taste, colour, shapes and it's very hard and difficult to avoid the children from consuming the junk foods. So, here mother plays a very important role to maintain the good health of the children by providing them the good nutritious food, it is a challenging task to mother to feed the child with the nutritious veggies or leafy veggies on daily basis, children are more attracted to the colorful food with different shapes, so here the dosas are prepared with the different purees of healthy veggies, leafy veggies, and named them as pink, green, orange dosas, here the child will be getting attracted towards the colour of the dosas and magical names, the pizza and noodles/maggi is to be prepared with the puree of the all veggies by this the children will be adopted to eat the healthy pizza/noodles. As children likes more ice-cream and chocolate but they refuse to eat the fresh fruits so here one can dip the freshly cut fruits into chocolate and can be given to the child. To avoid the chips, Kurkure one can prepare the condiments in the home by using ghee to fry and can be added to the empty Kurkure packets and can attract the children. This is one type of the Jigupsa Chikitsa which can be useful to avoid the malnutrition that take place in the child and to make child healthy by feeding the healthy products to the child unknowingly.

\section{CONCLUSION}

Jigupsa Chikitsa play a very important role. Cooking the food with the innovative ideas, with innovative approach can help the mother to overcome the child nutritional related health issues.

\section{REFERENCES}

1. Agnivesha, Charaka Samhita, Sutra Sthana, 11 adhyayam, Vaidhya Jadhavaji Trikamji Acharya, 2010, Chaukambha Prakashan, 2010.

2. Agnivesha, Charaka Samhita, Vimana Sthana, 2 Adhyayam, Vaidhya Jadhavaji Trikamji Acharya, 2010, Chaukambha Prakashan, 2010.

3. P. V. Tiwari, Kashyapa Samhitha English translation, Chakhambha visvabharati, Varanasi, Reprint 2002, Khila Sthana, Chapter 4, Verse 6.

4. P. V. Tiwari, Kashyapa Samhitha English translation, Chakhambha Visvabharati, Varanasi, Reprint 2002, Khila Sthana, Chapter 4, Verse 11-12.

\section{Source of Support: Nil Conflict of Interest: None Declared}

How to cite this URL: Manjula: Art of Cooking W.S.R Child Nutrition - A Prospective Study. International Ayurvedic Medical Journal \{online\} 2021 \{cited April, 2021\} Available from:

http://www.iamj.in/posts/images/upload/887_889.pdf 